\title{
Influence of projection angle in sandblasting cleaning on detrictic stone materials in Architectural Heritage
}

\author{
M.A. Iglesias-Campos ${ }^{\mathrm{a}, \mathrm{b}} \bowtie$, S. García-Fortes ${ }^{\mathrm{a}}$, J.L. Prada-Perez ${ }^{\mathrm{b}}$ \\ a. Universidad de Barcelona (Barcelona, Spain) \\ b. GRAPAC/CETEC-patrimoni Universidad Autónoma de Barcelona (Bercelona, Spain) \\ $\triangle$ manuel.iglesias@ub.edu
}

\author{
Received 15 March 2013 \\ Accepted 14 June 2013 \\ Available on line 30 May 2014
}

\begin{abstract}
In this research, the influence of the angle in abrasive blasting cleaning is studied on Montjuïc sandstone with black crust. After analyzing the properties of the soiling and the material, and their possible influence on the treatment, different cleaning tests were made at four different angles, keeping the complementary parameters constant. Taking the restorer's perspective as a starting point, and in order to fulfill the practical requirements of an intervention - time and cost reduction-, tests were evaluated with USB digital microscope, stereomicroscope with 3D visualization and measurement, and colorimeter. From the results it is established that angles close to $75^{\circ}$ minimize surface alteration, reducing differential erosion in the binding phases of detritic materials usually caused by this treatment.
\end{abstract}

KEYWORDS: Conservation; Restoration; Cleaning; Micro-sandblasting; Sandstone; Differential erosion

Citation / Citar como: Iglesias-Campos, M.A.; García-Fortes, S.; Prada-Pérez, J.L. (2014). Influence of projection angle in sandblasting cleaning on detrictic stone materials in Architectural Heritage. Mater. Construcc. 64 [314], e021 http://dx.doi.org/10.3989/mc.2014.02113.

RESUMEN: Influencia del ángulo de la proyección de abrasivos en la limpieza de materiales pétreos detríticos en Patrimonio Arquitectónico. En este trabajo se estudia la influencia del ángulo de la proyección de abrasivos en la limpieza de una arenisca de Montjuïc con costra negra. Tras analizar las propiedades del material, de la suciedad y su posible influencia en el tratamiento, se realizan diferentes catas de limpieza con cuatro ángulos distintos manteniendo constantes el resto de parámetros de la proyección. Partiendo de la visión del conservadorrestaurador y de un carácter práctico según las necesidades reales de una intervención — reducción de tiempos y costes - , los ensayos se evalúan con microscopio digital USB, microscopio estereoscópico con visualización y medición en 3D y colorímetro. De los resultados se puede determinar que ángulos cercanos a $75^{\circ}$ minimizan la alteración de la superficie al reducir la erosión diferencial de las fases de unión que el tratamiento normalmente provoca en los materiales detríticos.

PALABRAS CLAVE: Conservación; Restauración; Limpieza, Microproyección; Arenisca; Erosión diferencial

Copyright: (C) 2014 CSIC. This is an open-access article distributed under the terms of the Creative Commons Attribution-Non Commercial (by-nc) Spain 3.0 License.

\section{INTRODUCTION}

Mechanical cleaning by abrasive blasting is, among others, a technique used for many years to remove different surface deposits in Architectural Heritage. It is mentioned in most general publications of building materials treatment (1-4), in descriptive articles about the technique (5), in standards or recommendations for building cleaning (6-9), and on research and practical experiences (10-13).

As with any other cleaning technique, it presents some specific parameters affecting the final treatment results. However, analysing publications and 
standards in detail it can be ascertained that only general application parameters are described; and if considering the practical experiences, the question arises whether those parameters referred to are always the most useful to define the appropriate procedure.

To understand the influence of the different parameters it is necessary to recognize how to perform the treatment. Essentially, the conservatorrestorer cleans by the manual displacement of a nozzle that ejects air pressure and abrasive on a surface. Soiling is removed by the continuous incidence of different particles during a time determined by its visual observation and when the restorer considers the degree of cleanliness required has been reached. Depending on the influence of different technical factors associated with the technique, material and soil, a delicate treatment can be achieved or the substrate can be damaged. Alterations, if any, are related to the abrasion, impact or cutting mechanisms derived from the technique itself and they appear as differential erosion, loss of shine, microcracks, etc. (14), i.e. textural modifications favouring surface alteration and increasing the probability of greater re-soiling after treatment.

Together with material properties, such as heterogeneity, texture, cohesion and hardness, among others; dirt properties, especially thickness and adhesion; and equipment properties, sandblasting is influenced by pressure, distance, angle, time, nozzle, flow of particles, and specific abrasive properties (composition, size, specific weight, density, morphology, hardness, friability or toughness, etc.) because it is based on the kinetic energy formula $\left[E=1 / 2 m \times v^{2}\right]$, where $m$ is mass or abrasive; and $v$, velocity or pressure.

Most of these parameters are not specified in the studies. Pressure, the abrasive used, and usually its size are all that are mentioned, preventing accurate knowledge of how cleaning was done and the extrapolation of the results for similar situations.

The aim of the study is to analyse and evaluate some poorly documented aspects using simple analysis techniques readily available for the conservatorrestorer responsible for cleaning, investigating its usefulness in common situations, and in particular, the influence of the angle of projection.

As a parameter, this angle is not usually referred to except in some roughness tests (15) in some research papers (16) and in specific case studies $(10,12,17)$. In these cases, a $45^{\circ}$ angle is usually proposed as safer, compared to $90^{\circ}$; but certain observations appear to differ with these findings.

\section{EXPERIMENTAL}

Tests were made on a sculpted column fragment in Montjuïc sandstone of unidentified provenance. A preliminary study of the material and its alterations was made and with the data obtained the trials were proposed. Even though it is a documented stone material (18-20) samples were observed under stereomicroscope, and petrographic analysis of its texture and composition were made by SEM-EDX.

The cleaning results were analysed by digital microscope and colorimeter in order to observe changes on surface morphology and the degree of soil removal, because they are reasonably low-cost instrumentation for the restorer allowing an evaluation that could be performed in situ. Subsequently, to analyse further topographic changes, a stereomicroscope with $3 \mathrm{D}$ visualization and measurement was used in the laboratory. Because it is a mechanical cleaning method, optical techniques facilitated enough information potentially to take decisions in an actual intervention and allowed to distinguish relevant information about the studied parameters and their effects on the material.

Specifically, the devices used for cleaning evaluation were a USB digital microscope PCE-MM200 with $\times 10-200$ adjustable; a Leica M165C stereomicroscope with $\times 7.3-120$ adjustable with software Leica Stereo Explorer 3D visualizing and measurement, and a RM 110 de X-Rite colorimeter with $0.2 \mathrm{~mm}^{2}$ measurement area and NCS II colour chart. Additionally, to analyse texture and composition of the stone and the black crust a JEOL JSM-6300 scanning electron microscope fitted with a boronuranium EDX Link Isis-200 energy disperse spectrometer with a resolution of $138 \mathrm{eV}$ was used.

\subsection{Stone}

The stone is Montjuïc siliceous sandstone. This rock is mainly composed of quartz (80-90\% volume) and feldspars (orthoclase and plagioclase $<10 \%$ volume); to a minor degree it contains fragments of rock (schist, quartzite, etc.; between $0.5-2 \%$ volume) and muscovite. The mineral grains are generally equigranular with subangular forms; the cement is siliceous and the texture relatively homogeneous, quite compact and with visible mineral grain. In general this is a sandstone with a high quartz content and a cement which can vary between siliceous, clayey-siliceous and carbonated with the presence of iron oxides (20).

The fragment corresponds to the grey lithology o "pedra de blanqueig". It is a variety with a high content of quartz and slight amount of feldspar and mica. The grain size is diverse, although predominate grains between $300-500 \mu \mathrm{m}$, and their intergranular porosity is between $18-20 \%$ (18). The surface texture is smooth; smooth being understood in this case as microrough due to grain size, and worked with a claw chisel. The difference between peaks and valleys due to the surface finishing is between $400-600 \mu \mathrm{m}$.

The material was well preserved, although it has some flaking, pitting and occasional sanding related with soluble salts. It has a black crust of environmental origin, uniform in adherence and thickness, ranging 5-20 $\mu \mathrm{m}$, always higher in valleys that in peaks. 
Influence of projection angle in sandblasting cleaning on detrictic stone materials in Architectural Heritage $\mathbf{3}$

TABLE 1. Substrate parameters and possible influence on blasting cleaning

\begin{tabular}{llll}
\hline Layer & \multicolumn{1}{c}{ Properties } & & \multicolumn{1}{c}{ Influence } \\
\hline Black crust & Hardness & $\pm 4 \mathrm{Mohs}$ & Difficulty in cleaning \\
& Thickness & $5-20 \mu \mathrm{m}$ & Control need when reaching the substrate \\
& Adherence & High & Difficulty in cleaning \\
& Texture & Compact & Difficulty in cleaning \\
& Composition & Diverse (see section 2.1$)$ & It should not significantly affect \\
Sandstone & Mineralogy and & Quartz $(7 \mathrm{Mohs})$ & Alterability mainly due to hardness \\
& hardness & Feldspar $( \pm 6 \mathrm{Mohs})$ & variability and packing density \\
& & Mica $( \pm 2,5-3 \mathrm{Mohs})$ & \\
& Rock fragments & Difficulty in cleaning \\
& Porosity & $\pm 18-20 \%$ & Difficulty in cleaning \\
& Texture & Detritic & Difficulty in cleaning \\
\hline
\end{tabular}

Nowhere does the crust seem to affect the petrographic texture of the substrate. Its analysis by SEMEDX shows the usual residues of unburned carbon, sulphates and eolic silica particles with a slightly compact texture.

The difference in hardness between the main mineral and binding phases, and its detritic texture, increases the probability that the surface might be affected by differential erosion due to the treatment, taking into account, that with the cleaning was intended to remove a hard coating which, although quite thin, covered the stone material evenly and could affect areas in good condition and/or sanded. The roughness of the surface finish could also cause differences in the effect of the abrasive (Table 1).

\subsection{Methodology}

For the tests, the fragment, of $33 \times 8 \times 2.5 \mathrm{~cm}$, was placed vertically to simulate its position in a wall and four surfaces of $20 \mathrm{~cm}^{2}$ were generated (Figure 1).
The area was protected with special adhesive plastic tape for glazing, to provide a reference of the initial situation. The cleaning was made without shaping the ends of the treatment area, moving it and superimposing it on the protection.

A microsandblaster with $1.2 \mathrm{~mm}$ straight nozzle, 300 1/min flow compressor and air dryer were used. A pressure of 1 bar pressure on the manometer was selected because it is the minimum pressure at which most of the commercial equipment for sale or rent projects and, since it is commonly used for cleaning this stone material, aluminium silicate 80-160 $\mu \mathrm{m}$ was used. This product has irregular shapes, laminar and ridged, 7 Mohs hardness and is friable.

At every surface test the angle was modified and $25^{\circ}, 45^{\circ}, 75^{\circ}$ and $90^{\circ}$ angles were used. Regarding the distance, to unify the real measurement from end of the nozzle with the selected angles $10 \mathrm{~cm}$ was determined, that is the distance corresponding to the hypotenuse of the triangle formed between nozzle and surface with a distance of $4.3 \mathrm{~cm}$ at

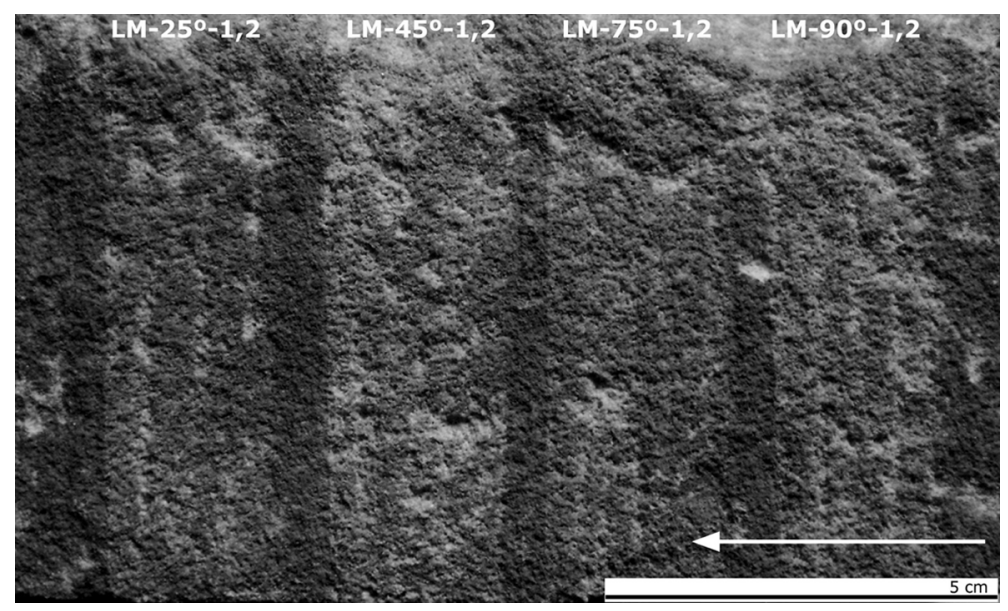

FIGURE 1. Image of the test areas with $1.2 \mathrm{~mm}$ nozzle. 
$25^{\circ}, 7.1 \mathrm{~cm}$ at $45^{\circ}, 9.7$ at $75^{\circ} \mathrm{cm}$ and logically, $10 \mathrm{~cm}$ at $90^{\circ}$. This distance was selected as one of the most usual ones when cleaning smooth surface with microsandblaster. To maintain distance and angle a reference rail was used.

Since, when the switch is activated there is a time in which the flow is not constant depending on pressure, hose length and product characteristics, among other influences, the samples were covered with a metal plate until a uniform and flowed projection was reached, at which time the trial was initiated to control as far as possible the homogeneity of the manual procedure. The same protective device was used to prevent the abrasive that continues to flow after releasing the drive control impacting with the surface at the end of the set time. Also, after cleaning, each testing was covered with paper to prevent visual and time comparisons that could influence the restorer's treatment. During tests an assistant was timing the duration of the projection and protecting and uncovering the surface. In time measurements a slight margin of error must be taken into account because it was not an automated system and so time must be understood as a reference to the speed of cleaning for treatment comparatives.

The samples were documented with macrophotography, USB digital microscope, stereomicroscope with $3 \mathrm{D}$ visualizing and measurement and colorimeter.

After analysing these surfaces two angles were selected, those which had caused the most and least damage, and the same tests were repeated but with straight nozzle of $1.8 \mathrm{~mm}$ in areas of the same size and with the same equipment cleaning and evaluation.

\section{RESULTS AND DISCUSSION}

The main differences between tests appear with slight changes in colour and tone. Visually, and although the differences are very slight, between the test surfaces can be seen some variations indicating a greater or lesser degree of cleanliness, or indirectly, alteration. The darker area corresponds to the surface treated with $75^{\circ}$ angle, and proceeds to clearer areas with $25^{\circ}, 90^{\circ}$ and $45^{\circ}$ (a priori darker coloration is interpreted as lesser alteration because less soil has been removed). The changes are intensified in each surface test because of the existence of lighter areas that match the claw chisel valley, and in isolated cases, with flaking and pitting previous to the cleaning. These points due to their thinner layer of dirt compared to those without these alterations, are dismissed in the overall assessment of the results of colour.

To document this numerically, a colorimeter with NCS II colour chart was used and the data are reflected in Table 2. The NCS II system describes the similarity of colour with two or more of the six basic colours. The initial S indicates that NCS edition 2 standard is used, and the first four digits represent the percentage hue of blackness and chromaticity; the rest, up to a maximum of $100 \%$, represent the colour whiteness. The second notation represents the colour tone and describes the percentage similarity with the two chromatic elementary colours that in these measurements are yellow (Y) and red (R). The numeric value indicates the percentage of redness and the rest, up to $100 \%$, the yellowness.

Thus, the reading taken at seven different points of each treated surface indicates (Table 2):

- the untreated surface has a very dark brown colour (hue $60 \%$ blackness, $5 \%$ chromaticity and $35 \%$ whiteness; and tone with $80 \%$ yellowness and $20 \%$ redness).

- the stone in fractured surface has a light grey colour (hue 20\% blackness, $5 \%$ chromaticity and $75 \%$ whiteness ; and tone with $50 \%$ yellowness and $50 \%$ redness).

- surfaces treated with $75^{\circ}$ and $25^{\circ}$, the least affected in this order, have a dark brown colour (hue $50 \%$ or $40 \%$ blackness, $5 \%$ chromaticity and $50 \%$ or $60 \%$ whiteness; and tone $80 \%$ yellowness and $20 \%$ redness).

- the surface treated with $45^{\circ}$ and $90^{\circ}$, the most affected in this order, have lighter shades of dark brown (hue $30 \%$ or $40 \%$ blackness, $5 \%$ chromaticity and $75 \%$ or $60 \%$ whiteness; tone $80 \%$ yellowness and $20 \%$ redness).

The variations are generally very subtle. From the colour of the untreated surface no changes of hue are caused, although in all measurements the hue of initial blackness diminishes (higher with $45^{\circ}$ and $90^{\circ}$ )

TABLE 2. NCSII colour measurements on untreated stone, on stone fracture, on test areas and indication of the number of measurement repetitions

\begin{tabular}{|c|c|c|c|c|}
\hline Layer & $\begin{array}{c}\text { Nozzle } \\
(\mathrm{mm})\end{array}$ & Angle & $\begin{array}{c}\begin{array}{c}\text { Colour } \\
\text { measurement } \\
(\text { NCS II) }\end{array} \\
\end{array}$ & $\begin{array}{c}\text { Repetition } \\
\text { measurement }\end{array}$ \\
\hline $\begin{array}{l}\text { Stone untreated } \\
\text { (soiling) }\end{array}$ & & & S 6005-Y20R & 7 \\
\hline Stone in fracture & & & S 2005-Y50R & 7 \\
\hline \multirow[t]{6}{*}{ Treated stone } & 1,2 & $25^{\circ}$ & $\begin{array}{l}\text { S 5005-Y20R } \\
\text { S 4005-Y20R }\end{array}$ & $\begin{array}{l}4 \\
3\end{array}$ \\
\hline & 1,2 & $45^{\circ}$ & $\begin{array}{l}\text { S 3005-Y20R } \\
\text { S 4005-Y20R }\end{array}$ & $\begin{array}{l}5 \\
2\end{array}$ \\
\hline & 1,2 & $75^{\circ}$ & $\begin{array}{l}\text { S 4005-Y20R } \\
\text { S 5005-Y20R }\end{array}$ & $\begin{array}{l}6 \\
1\end{array}$ \\
\hline & 1,2 & $90^{\circ}$ & $\begin{array}{l}\text { S 4005-Y20R } \\
\text { S 3005-Y20R }\end{array}$ & $\begin{array}{l}4 \\
3\end{array}$ \\
\hline & 1,8 & $45^{\circ}$ & $\begin{array}{l}\text { S 3005-Y20R } \\
\text { S 4005-Y20R }\end{array}$ & $\begin{array}{l}6 \\
1\end{array}$ \\
\hline & 1,8 & $75^{\circ}$ & $\begin{array}{l}\text { S 4005-Y20R } \\
\text { S 5005-Y20R }\end{array}$ & $\begin{array}{l}5 \\
2\end{array}$ \\
\hline
\end{tabular}


and, therefore, the whiteness increases, reflecting a degree of cleaning and/or damage. The colour difference on the surfaces after cleaning is related, therefore, with the reduction of blackness.

After visual and colorimetric analysis, and studying the surfaces in detail, it can be seen that all have different degrees of alteration and dirt, and that differences are more pronounced according to the angle used. Angle seems to be related, therefore, with the alteration caused.

To evaluate these results, it should be noted that in all the trials traces of dirt remain between the grains, but not on its surface. The high packing density of the sample (average $80.72 \%$ ) and the angle used in the cleaning has caused different shielding and protection effects between minerals, documented in other studies (16), which have prevented the arrival of the abrasive to the deepest points. It should also be noted, that the intergranular space is varied, ranging between 20 and $215 \mu \mathrm{m}$, similar in many cases to the size of the abrasive used.

From the analysis of the tests with USB digital microscope (Figure 2) and stereomicroscope with visualization and measurement in 3D (Figures 3-4), it can be observed that the main damage has been produced in the binding phases of the stone minerals, provoking the detachment of the mineral grains according to the angle used.

By schematising the abrasive effect on the surface the reason can be determined/found (Figure 5).
When projecting at $25^{\circ}$ with a ridged, laminar and friable abrasive, the major mechanism is a friction with reduced impact acting mainly above the sandstone grains or between the intergranular spaces where it can penetrate. Because it is a sloping angle, it decreases the impact energy and reduces the detachment of minerals. The general degree of cleanliness is low, confirmed with colour measurements, because the abrasive does not reach all the surface. Instead, the original claw chisel valleys become clearer because, due to the projection angle, the product can penetrate in the tool depression, causing also a collision and rebound provoking the treatment reincidence. This cavitation generates in these areas a higher damage by erosion and a greater cleaning effect.

The greatest alteration is observed with $45^{\circ}$ angle. Schematising the cleaning mechanism shows that the abrasive has the capacity to penetrate most of the surface valleys, acting on peaks with a combined friction and impact mechanism. In the claw chisel grooves cavitation occurs and damage is increased by a greater impact energy than with $25^{\circ}$ : the attack is strongest on binding phases facilitating the detachment of the grains. The surface after this cleaning is clearer.

With $75^{\circ}$ the penetration of the abrasive between the intergranular spaces is reduced, as confirmed by the remaining dirt. Although the impact slightly increases, it reduces friction and cavitation in the
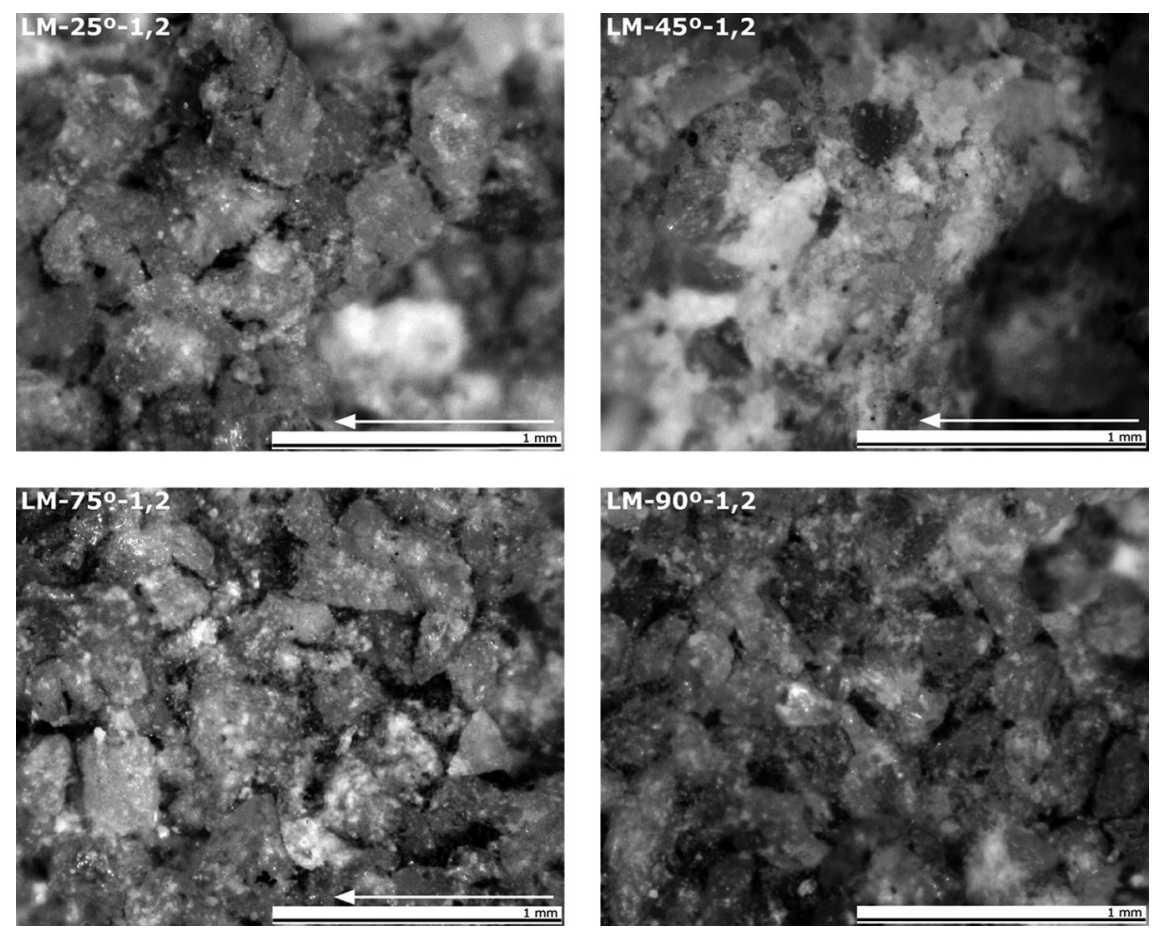

FIgURE 2. Detail of the tests after cleaning with $1.2 \mathrm{~mm}$ nozzle on the toothed chisel valley - arrow: blasting direction - USB digital microscope image. 

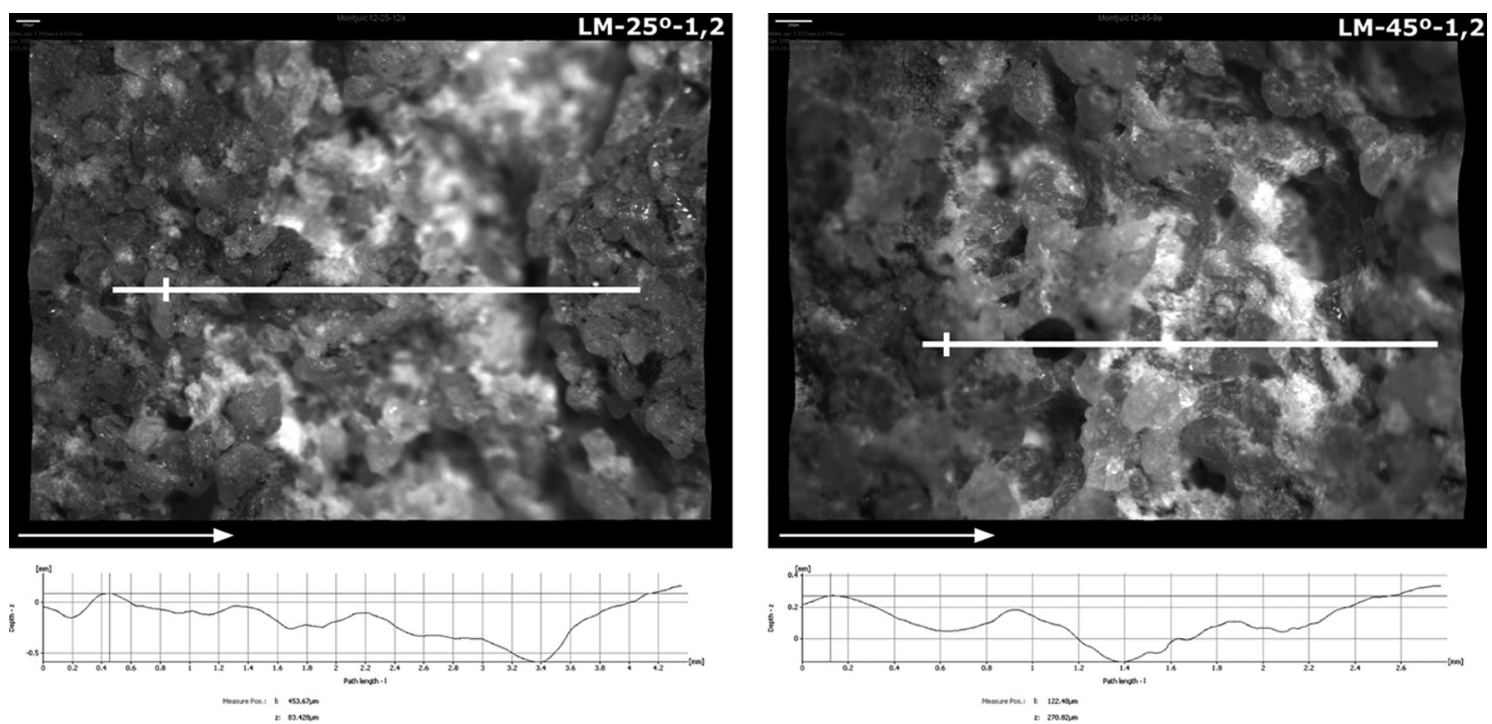

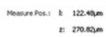
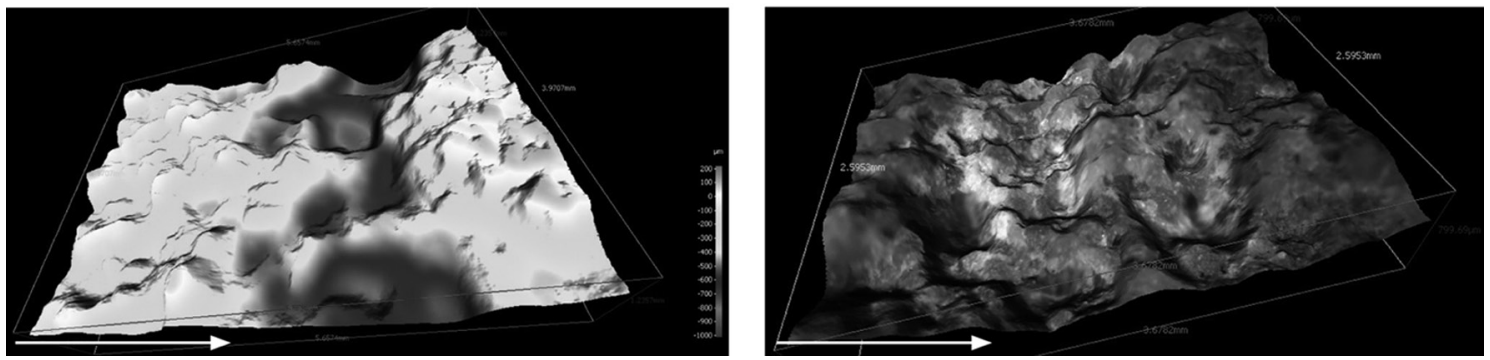

FIGURE 3. Detail of the topography and primary profile after cleaning with $25^{\circ}$ and $45^{\circ}$ on the toothed chisel valley — arrow: blasting direction -. Stereomicroscope with 3D visualizing and measuring image. Scale $200 \mu \mathrm{m}$.
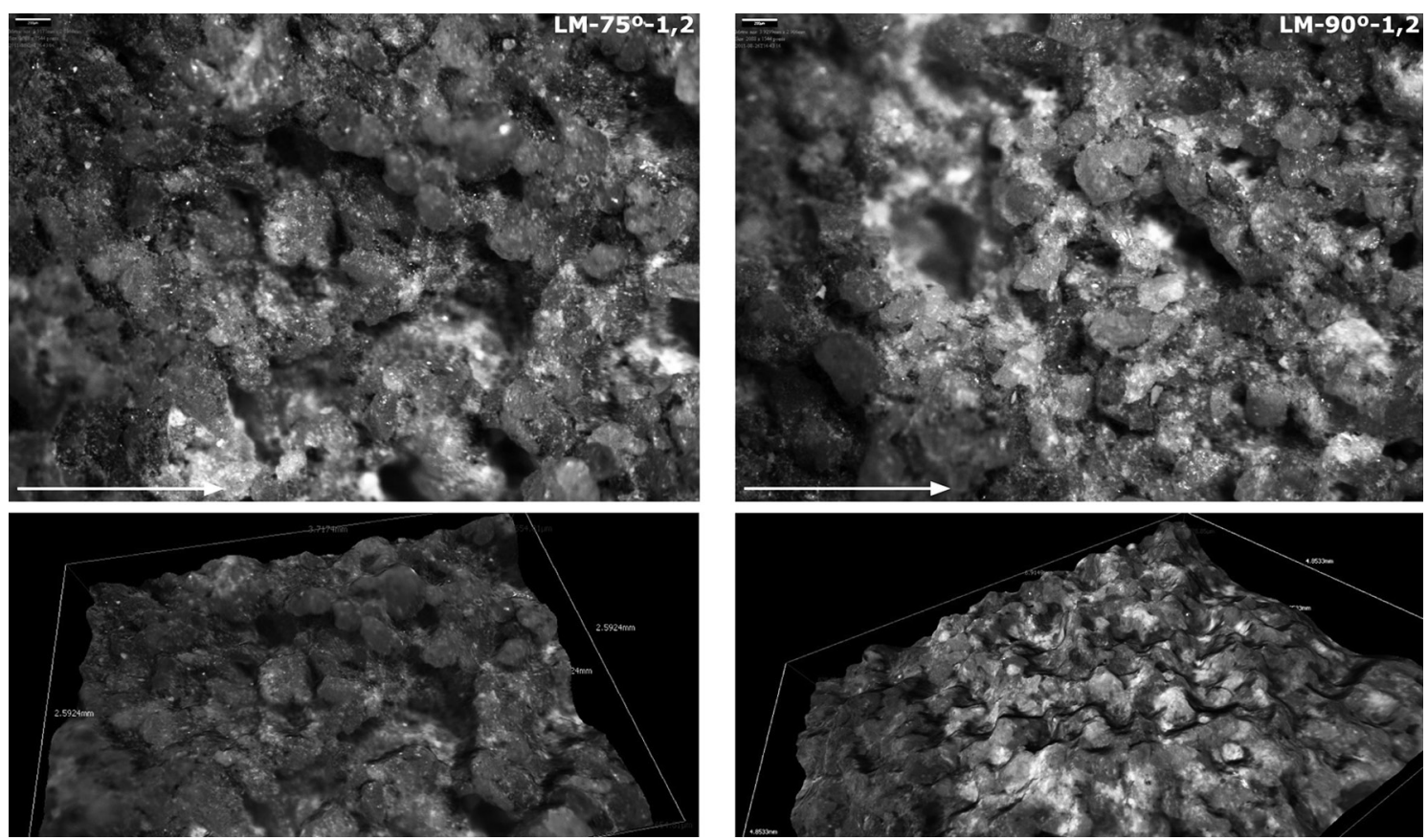

FIGURE 4. Detail of the topography after cleaning with $75^{\circ}$ and $90^{\circ}$ on the toothed chisel valley — arrow: blasting direction - Stereomicroscope with 3D visualizing and measuring image. Scale $200 \mu \mathrm{m}$. 

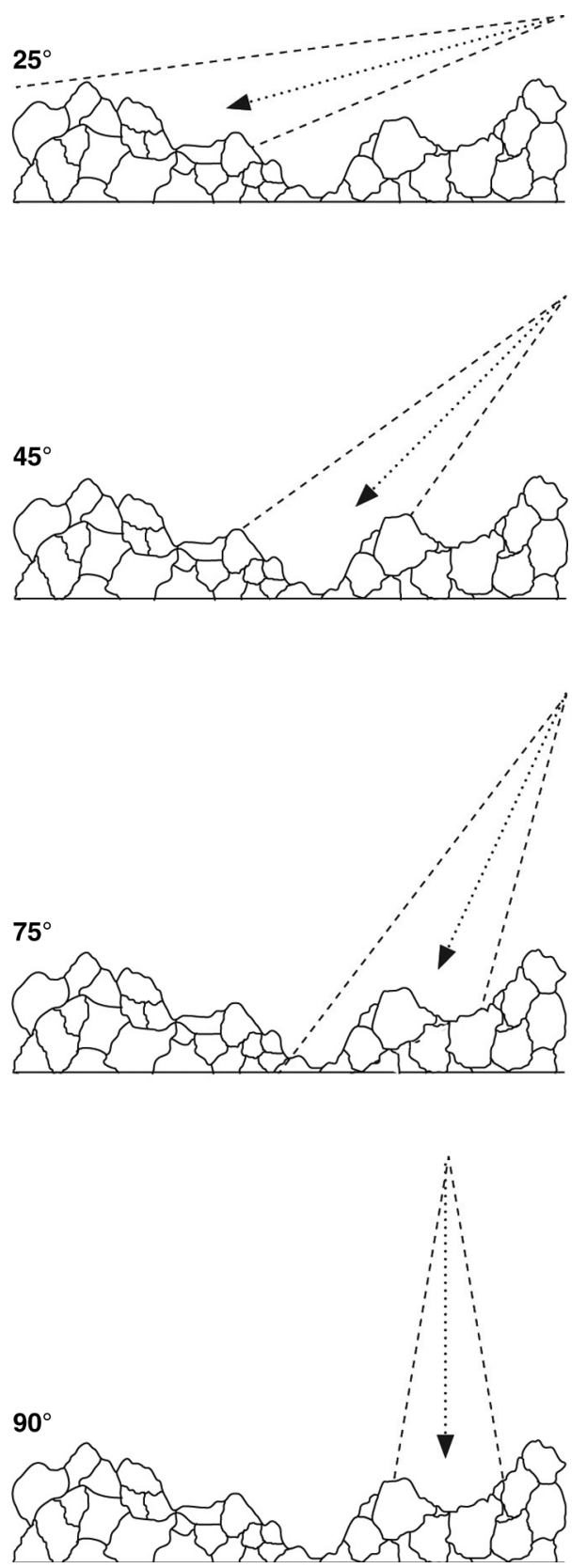

FIGURE 5. Blasting scheme on the surface with the different angles used in the trials.

groove of the claw chisel, but light pitting is observed on the surface of the mineral grains manifested as visual brightness loss. A lower friction reduces erosion in the binding phases and minerals are not detached. The surface is darker.

At $90^{\circ}$, the impact mechanism is higher and the friction action is eliminated. The cleaning attacks the surface more directly both in peaks and in valleys and more superficial pitting on mineral grains is produced. Although cavitation is reduced or almost eliminated, the particles whose size penetrate the between the intergranular space attack more the binding phases. The treatment causes an irregular detachment of the mineral grains. Even so, the modification is lesser than at $45^{\circ}$ angle, and it seems to confirm that at this angle alteration in the binding phases occurs mainly by a friction mechanism.

In general, the heterogeneous texture of the fragment's surface finish prevents observation by touch or its reflection with numerical values of roughness.

Depending on the angle a reduction has also been observed in the treatment time, the more open, the less the duration. Thus, $25^{\circ}$ takes $12 \mathrm{~s}$ to clean the surface, with $45^{\circ}, 9 \mathrm{~s}$; with $75^{\circ}, 7 \mathrm{~s}$; and with $90^{\circ}, 4 \mathrm{~s}$. This reduction is related with the spot shape when the abrasive comes out the nozzle and impacts on the surface, from elliptical to circular depending on the angle. In these cases, the smaller treated area which is the $90^{\circ}$ angle is compensated in terms of dirt removal by increasing the impact strength: more quantity is removed but more aggressively. Note that, although the duration is short, in all the tests visual control was possible of the removed soil, except at $90^{\circ}$, where dust was more concentrated and made visual control more difficult.

As mentioned, after obtaining these results the test was repeated maintaining the constant parameters, and selecting the angles that have caused major and minor alteration $\left(45^{\circ}\right.$ and $75^{\circ}$, respectively) but increasing the nozzle diameter to $1.8 \mathrm{~mm}$ (Figure 6).

In the visual analysis with magnifying optical techniques (Figure 7) and colour measurement (Table 2), similar results are obtained. Although damage is minimized, each angle provides cleaning and alteration similar to previous tests.

With $45^{\circ}$, comparable mechanisms are deduced: the abrasive has the capacity to penetrate most of the valleys and act on peaks with a combined mechanism of friction and impact. In the groove of the carving tool some cavitation occurs, attacking the binding phases and facilitating the detachment of the mineral grains. The hue of blackness decreases in the same way as in the preceding tests (Table 2) obtaining a lighter surface. $75^{\circ}$ angle, reduces erosion of the binding phase and the mineral grains are not detached. With both angles dirt remains in the intergranular spaces due to the shielding produced by the grains according to the angle of incidence of the abrasive but less than with $1.2 \mathrm{~mm}$ nozzle.

Keeping all parameters constant, the decrease of the alteration appears to be related to the increased nozzle diameter. The increase of $0.6 \mathrm{~mm}$ in diameter indirectly reduces the abrasive impact energy, since in a larger space the same amount of product goes through without contracting the flow and the energy of air dissipates because it is not so channelled. 


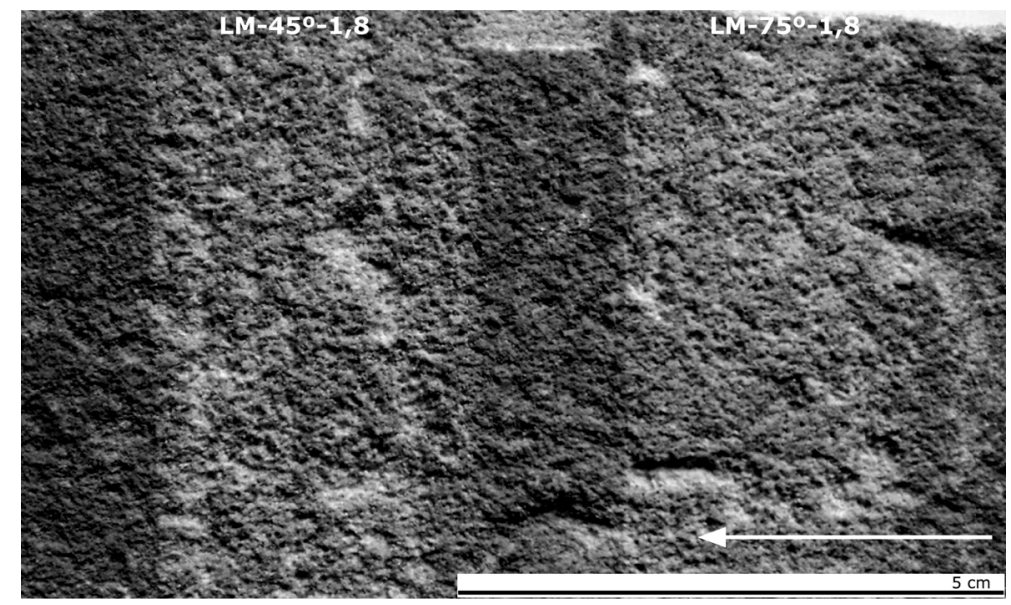

FIGURE 6. Image of the test areas with $1.8 \mathrm{~mm}$ nozzle.
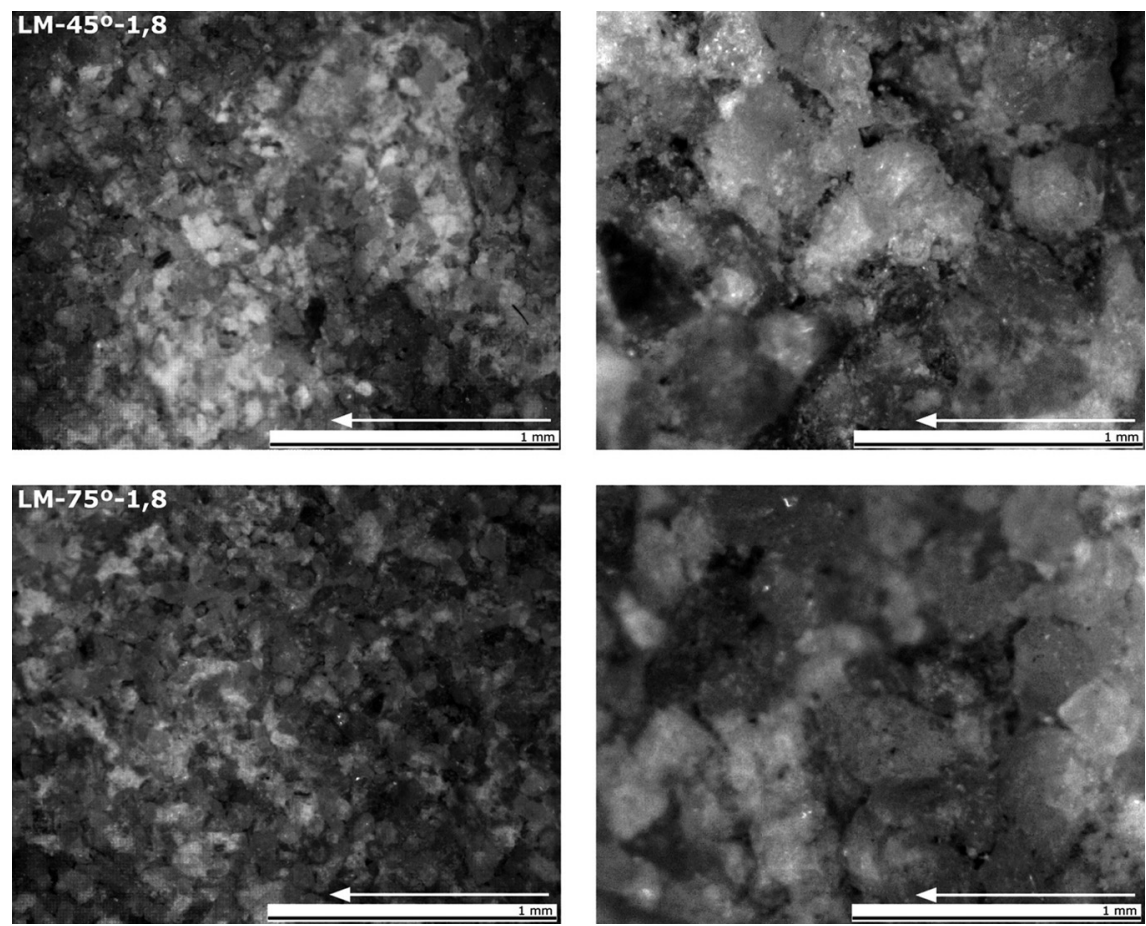

FIGURE 7. Detail of the tests after cleaning with $1.8 \mathrm{~mm}$ nozzle on the toothed chisel valley - arrow: blasting direction - . USB digital microscope image.

\section{CONCLUSIONS}

As has been demonstrated, keeping the other parameters constant, the angle modifies the effects of an abrasive blasting cleaning on detritic materials due to differential erosion caused. Of those tested, the $75^{\circ}$ angle is the angle that produced least alterations. It has also been found that the more upright the angle, the faster the rate of treatment, and that increasing the nozzle diameter, with all other parameters constant, including the angle, the alteration of the material minimizes because it indirectly reduces the abrasive pressure.

Evaluation of the results using simple techniques which allow comparative optical observation at different scales has been sufficient for a study according to actual needs of intervention (reduction of time and costs). The surface analysis with macrophotography and USB digital microscope in situ and stereomicroscope with $3 \mathrm{D}$ visualization 
and measurement in laboratory have provided satisfactory information for assess the effects of this mechanical cleaning technique. Direct observation and the images obtained, supplemented by other optical techniques such as colorimetry, have clarified the results because, essentially, dirt is perceived as a modification of visual parameters of that considered to be an original and clean surface.

\section{REFERENCES}

1. Lazzarini, L.; Laurenzi Tabasso, M. (1986) Il restauro della pietra, CEDAMM, Padova.

2. Ashurst, N. (1994) Cleaning historic buildings, Vol. 2: Cleaning materials and processes, Donhead Publishing, London

3. Esbert, R.M.; Ordaz, J.; Alonso, F.J.; Montoto, M. (1997) Manual de diagnosis y tratamiento de materiales pétreos y cerámicos. Manuals de Diagnosi, [5], Barcelona: Col.legi d'Aparelladors i Arquitectes Tècnics de Barcelona.

4. Vergès-Belmin, V.; Bromblet, P. (2000) Le nettoyage de la pierre, Monumental. Revue scientifique et technique des Monuments Historiques, 220-273.

5. Iglesias Campos, M. (2010) Métodos mecánicos para la limpieza de materiales constructivos: proyección de abrasivos a baja presión. In: Gisbert Aguilar, J. (ed.). La tecnología láser y otros métodos de limpieza y restauración de materiales pétreos. Documentos para la caracterización y restauración del patrimonio histórico. Cuadernos Arbotante [1]. Libros Pórtico, Zaragoza, 29-43.

6. Commissione Normal. CNR-ICR (1986) Normal 20/85. Interventi conservativi: progettazzione, esecuzione e valutazione preventiva.

7. BS 8221-1:2000 (1986) Code of practice for cleaning and surface repair of buildings. Part 1: Cleaning of natural stones, brick, terracotta and concrete.

8. ASTM International: E1857-97 (2004). Standard guide for selection of cleaning techniques for masonry, concrete and stucco surfaces.

9. AENOR: UNE 41806-3:2009 (2009) In: Conservación de edificios. Limpieza de elementos constructivos. Parte 3: Técnicas de limpieza mecánica.
10. Iglesias, M.; Gea, B.; Prada, J.L.; Guasch, N. (2006) Lowpressure abrasive cleaning of historic building materials. Proc. of the International Heritage, Weathering and Conservation Conference (HWC-2006), Madrid, Fort, R.; Álvarez de Buergo, M.; Gómez Heras, M. \&Vazquez-Calvo C. (eds.), Spain,Taylor \& Francis, London, 681-686.

11. Alonso, F.J.; Esbert, R.M.; Ordaz, J.; Valdeón, L.; Rojo, A.; Mateos, F. (2007) El claustro de la catedral de Oviedo: conservación de la piedra. In: Restauradores sin Fronteras e Instituto de Geología Económica (CSIC-UCM) (ed.). Ciencia y tecnología para una conservación sostenible del Patrimonio Pétreo, Boceto, Madrid, 13-21.

12. Iglesias, M.; Prada, J.L.; Guasch, N. (2008). Technique for cleaning Tarragona Miocene age dolomitized silty limestone, altered by urban pollution. Mater. Construcc., vol. 58, [289-290], 247-262. http://dx.doi.org/10.3989/mc.2008.v58. i289-290.

13. Perez-Monserrat, E.M.; Varas, J.M.; Fort, R.; de Buergo, M.A. (2011) Assessment of different methods for cleaning the limestone facades of the former workers Hospital of Madrid, Spain, Studies in: Conservation, 56, [4], 298-313. http://dx.doi. org/10.1179/204705811X13159282692969.

14. Young, M.E.; Urquhart, D.C.M.; Laing, R.A. (2003) Maintenance and repair issues for stone cleaned sandstone and granite building façades, Building and Environment. 38, [9-10],1125-1131.http://dx.doi.org/10.1016/S0360-1323(03) 00084-2.

15. Grissom, C.A.; Charola, A.E.; Wachowiak, M.J. (2000) Measuring surface roughness on stone: back to basics. Studies in Conservation, 45, [2], 73-84. http://dx.doi.org/ 10.1179/sic.2000.45.2.73

16. Blanco Domínguez, M. (2000) Aplicación del láser y de la proyección de abrasivos en rocas ornamentales y de cantería aragonesas. Tesis doctoral. Universidad de Zaragoza.

17. Iglesias, M. (2000) Un ensayo de limpieza de superficies delicadas por proyección de abrasivos a baja presión, $A K O B E$. Restauración y conservación de bienes culturales, [4], 13-16.

18. Esbert, R.M.; Ordaz, J.; Alonso, F.J. (1999) Anàlisi i pautes d'actuacions en els elements de pedra de les façanes de l'Eixample de Barcelona. Pro-Eixample, Barcelona.

19. Farrando Boix, R. (1999) La pedra de Montjuïc de la Catedral de Barcelona. Publicació La Busca, Barcelona.

20. Gómez-Gras, D.; Parcerisa, D.; Calvet, F.; Porta J.; Solé De Porta N.; Civís, J. (2001) Statigraphy and petrology of the Miocene Montjuïc delta (Barcelona, Spain). Acta Geológica Hispánica, 36, [1-2], 115-136. 